\title{
The Faithless Employee: A Case Involving the Legal and Accounting Issues Associated with Employee Theft of Company Funds
}

Robert Gruber, (E-mail: gruberr@uww.edu), University of Wisconsin-Whitewater James Molloy, (E-mail: molloyj@uww.edu), University of Wisconsin- Whitewater

\begin{abstract}
This case explores the areas of public accounting/auditing and business law as they relate to the conduct of an employee who intentionally and unlawfully obtains, and, negotiates for his own benefit, his employer's negotiable instruments (checks). In particular, this case involves an accountant who unlawfully acquired negotiable instruments, purportedly drawn by the employer and made payable to the accountant as a result of the accountant's improper use of his employer's computerized accounting system. Because of his position, his knowledge of the system, and the lack of proper accounting controls, he was able to write company checks to himself and to manipulate the deductions to his paycheck.
\end{abstract}

\section{Introduction}

$\mathrm{T}$ The scenario presented in this case is unfortunately all too common in business, and, as a matter of fact, this case is based on an actual incident. It raises issues relating to business law (negotiable instruments), criminal law, ethics, as well as issues relating to auditing and control. It involves an accountant, who because of his position, his knowledge of the company's computerized accounting system, and the lack of proper accounting controls, was able to fraudulently write company checks to himself and to manipulate the deductions to his paycheck. This case explores the circumstances that could give rise to such nefarious activities and the ramifications of such activities, both legal and accounting.

\section{Company Background}

Brothers Joe and Frank Johnson established Johnson Foundries in Milwaukee, Wisconsin in 1951. The company specializes in manufacturing metal parts for the automobile industry. Initially, they had a workforce consisting of ten employees out on the shop floor. Joe was in charge of managing the operation and Frank looked after sales. Business was brisk in the 1950's and 1960's, and after several moves to larger quarters, in 1970 they comfortably settled into their current factory in Waukesha, Wisconsin. Johnson Foundries is a respected name in the community and currently has revenues of 50 million dollars a year and a workforce of two hundred people.

In 1990, both Joe and Frank decided it was time to hand over the reins of the company to the next generation and retire to Florida. As is often the case, however, the next generation, consisting of Joe's only child, John, and Frank's two children, Samantha and Curt, wasn't always up for the challenge. All received business degrees from the local university, but their only business experience was with Johnson Foundries. Samantha did an admirable job carrying on her father Frank's tradition of excellent sales representation and customer service, but back at the office, John, President, and Curt, Vice President of 
Finance, weren't managing the business as effectively or as conscientiously as Joe had done. Joe's motto had always been, "Look after the pennies, and the dollars will look after themselves." John and Curt, however, were much more interested in the perks of their offices than in looking after the affairs of their business. They were very active in the local country club and spent a good deal of time on the links. Of course, this meant that they did not spend as much time on their business as they should have, and while sales were still strong and the customers still quite happy, thanks to the efforts of Samantha and their loyal employees, they were not physically around or as involved as much as they should have been. As a matter of fact, Curt had all but turned over control of the company's finances to a long-term employee of the firm, Charles Smith. Charles had been hired by Joe in 1985 as a staff accountant. From the beginning, everyone had been impressed with how hard Charles had worked and the hours he kept. He was always in by 7:00 AM and most days stayed until 6:00 PM. He ate lunch at his desk every day and hadn't taken a vacation in ten years. Accordingly, he rose through the ranks, received promotion after promotion, and ultimately became manager of the accounting department and, among other things, was responsible for issuing payroll checks. In the late 1990's, Charles had been instrumental in developing and implementing the company's computerized accounting system.

\section{The Computer System}

Charles was very excited when John, Curt, and Samantha approached him in 1997 to design and acquire the company's first, fully computerized accounting system. As usual, they didn't want to be bothered with the details, trusting Charles to "handle the whole thing." "After all," they thought, "who was better qualified than Charles and who would be working with the new system most of the time, anyway?”

So Charles called a close friend from high school who had been recently "downsized" and started his own computer consulting company. Together, Charles and his friend spent nearly three-months developing, acquiring, and implementing the new computerized accounting system. The company's external auditors were contacted on several occasions regarding specific issues related to the annual audit and the reports generated by the new system. He did not consult them on internal controls issues. Charles hoped the efficiency of the computerized reports would save the company some audit fees in the upcoming year.

Several significant short-cuts were taken in the acquisition process. First, a detailed analysis of the company's needs and requirements, including the strengths and deficiencies of the current system, were hastily conducted. Second, bids were only submitted by two vendors; of course, Charles accepted the lowest bid because "it was the lowest bid." Finally, Charles decided that the payroll function would use on-line, real-time processing instead of the batch processing system recommended by both the vendor and Charles' friend. "Batch processing is too slow," argued Charles, "and we need to be responsive to our employees' desire to be paid quickly." His friend stated that Johnson Foundries wasn't large enough to warrant such an expensive add-on feature. "Besides," she explained, "a separate payroll department is needed so as to fully implement the required internal controls structure.” Charles wasn't convinced and ordered the on-line, real-time payroll system anyway.

\section{The Crime}

Unbeknownst to anyone, over the past four years Charles had been periodically writing extra payroll checks made payable to himself (payee) on the company's checking account (drawer) with Second Bank (drawee). These checks were negotiated by Charles to Third Bank with the proceeds deposited in Charles' checking account there and the funds were later withdrawn by him for his own personal use. Ultimately, Charles received $\$ 45,421.67$ as a result of his fraudulent activities. 
Additionally, given Charles' expert knowledge of the company's computerized accounting system, he was able to manipulate the payroll program and occasionally omitted the deductions for his federal taxes, state taxes, health insurance premiums, FICA, and other payroll deductions on his payroll checks. Over the past three years, he had acquired \$40,507.31 as a result of these fraudulent activities.

In July of 2003, Charles' father was stricken by a severe heart attack and needed to be attended to by Charles for a period of about two weeks. During this time his duties were temporarily assigned to Agatha Simmons, who accidentally, discovered Charles' nefarious activities and brought them to the attention of Curt. Curt immediately contacted the police and Second Bank.

After securing legal counsel, Curt, on behalf of Johnson Foundries, followed-up with the local District Attorney, and a criminal complaint was filed against Charles Smith. He then demanded that Second and Third Banks return all the money they had handled in the payment of these checks. They have refused. It also turns out that Charles' had spent all of his ill-gotten gains and is broke.

\section{Questions}

1. Can Johnson Foundries civilly pursue either Second Bank or Third Bank for the restoration of its funds?

2. Is Charles Smith criminally liable for his conduct?

3. What could Johnson Foundries have done to have prevented this type of employee theft?

\section{Instructors Notes}

\section{Teaching Objectives}

The teaching objectives of this case are to provide students with a background for:

- Correctly identifying the legal and accounting issues associated with this case.

- Demonstrating and understanding of how to research and acquire the legal statutes and other materials that will be involved in the determination of this matter both civilly and criminally.

- Demonstrating an understanding of the appropriate accounting control procedures associated with businesses of this type.

- Interpreting, evaluating and analyzing the appropriate legal and accounting materials associated with the determination of this matter, both civilly and criminally.

- Recommending a solution that might be utilized to prevent this type of activity in the future or in other business contexts.

\section{Can Johnson Foundries civilly pursue either Second Bank or Third Bank for the restoration of its funds?}

It appears at first blush, that this case generally falls within the area of the "Padded Payroll" rule of the Uniform Commercial Code Sec. 3-405. A bank will ordinarily be held liable for paying a check that contains a forged endorsement. However, Sec 3-405 (b) states:

For the purpose of determining the rights and liabilities of a person who, in good faith, pays an instrument or takes it for value or for collection, if an employer entrusted an employee with responsibility with respect to the instrument and the employee or a person acting in concert with the employee makes a fraudulent endorsement of the instrument, the endorsement is effective as the endorsement of the person to whom the instrument is payable if it is made in the name of that person. If the person paying the instrument or 
taking it for value or for collection fails to exercise ordinary care in paying or taking the instrument and that failure substantially contributes to loss resulting from the fraud, the person bearing the loss may recover from the person failing to exercise ordinary care to the extent the failure to exercise ordinary care contributed to the loss.

As a result, it seems that these instruments are valid and enforceable despite their irregular issuance. Most likely, Second and Third Banks exercised good faith and ordinary care in the paying and processing of the checks. The employer (Johnson Foundries) entrusted an employee (Charles Smith) with the responsibility of issuing checks on behalf of the corporation. And, the faithless employee made the fraudulent endorsement in his own name. Also, as stated in Official Comment 1 of Section 3-405, it states:

Section 3-405 adopts the principle that the risk of loss for fraudulent endorsements by employees who are entrusted with responsibility with respect to checks should fall on the employer rather than the bank that takes the check or pays it, if the bank was not negligent in the transaction. Section 3-405 is based on the belief that the employer is in a far better position to avoid the loss by care in choosing employees, in supervising them, and in adopting other measures to prevent forged endorsements on instruments payable to the employer or fraud in the issuance of instruments in the name of the employer.

However, this case is set forth specifically in Official Comment 3, Case \#2 of Section 3-405, which by example states:

$\mathrm{X}$ is Treasurer of Corporation and is authorized to write checks on behalf of corporation by signing X's name as Treasurer. X draws a check in the name of the corporation and signs $\mathrm{X}$ 's name as Treasurer. The check is made payable to $\mathrm{X}$. $\mathrm{X}$ then endorses the check and obtains payment. Assume that corporation did not owe any money to $\mathrm{X}$ and did not authorize $\mathrm{X}$ to write the check. Although the writing of the check was not authorized, Corporation is bound as drawer of the check because $\mathrm{X}$ had authority to sign checks on behalf of Corporation. This result follows from agency law and Section 3-402 (a). Section 3-405 does not apply in this case because there is no forged endorsement. X was payee of the check so the endorsement is valid. Section 3-110 (a).

Accordingly, while we look to Sect. 3-405 for guidance and commentary, this is technically an issue of Smith indorsing an instrument made out to him as payee in his own name. There really isn't a forged endorsement. Unfortunately for Johnson Foundries, they are still liable.

Even setting aside any defenses by the banks of the running of the appropriate Statute of Limitations or other claims they may have, it appears that the drawer (Johnson Foundries) is responsible for these instruments. Should one wish a more exhaustive analysis of Section 3-405, it can be found in an excellent annotation in 45 ALR $5^{\text {th }} 389$.

\section{Is Charles Smith criminally liable for his conduct?}

In all states Charles Smith would be liable for his conduct. For example, in Wisconsin, his conduct would run afoul of Wis. Stats. Sec. 943.20 MISAPPROPRIATION, which states:

943.20 Theft. (1) ACTS. Whoever does any of the following may be penalized as provided in sub. (3): (b) By virtue of his or her office, business or employment, or as trustee or bailee, having possession or custody of money or of a negotiable security, instrument, paper or other negotiable writing of another, intentionally uses, transfers, 
conceals, or retains possession of such money, security, instrument, paper or writing without the owner's consent, contrary to his or her authority, and with intent to convert to his or her own use or to the use of any other person except the owner. A refusal to deliver any money or negotiable security, instrument, paper or other negotiable writing, which is in his or her possession or custody by virtue of his or her office, business or employment, or as trustee or bailee, upon demand of the person entitled to receive it, or as required by law, is prima facie evidence of an intent to convert to his or her own use within the meaning the of this paragraph.

If convicted, pursuant to Wis. Stats. Sec. 943.20 (3) (c), he would be guilty of a Class G Felony and face a possible fine not to exceed $\$ 25,000$ or imprisonment not to exceed ten years, or both, on each count, since Charles Smith by virtue of his employment unlawfully and intentionally had possession of money and other negotiable instruments, and concealed and retained possession of such money and other negotiable instruments belonging to Johnson Foundries with a value in excess of $\$ 10,000$, without the owner's consent, contrary to Smith's authority and with intent to convert this property to his own use.

While Charles Smith may pay his debt to society in prison, that won't help Johnson Foundries though, inasmuch as Charles Smith is impecunious.

\section{What could Johnson Foundries have done to have prevented this type of employee theft?}

Note: Problems in this case started during the development phase for the new computerized accounting system. Charles was given too much control (and autonomy) over the project and had virtually no reporting responsibility to the owners.

The objectives of internal controls systems are to provide reasonable assurance that (1) assets are safeguarded and used for business purposes, (2) business information is accurate, and (3) employees comply with laws and regulations.

The specific objectives of internal controls for payroll are to ensure (1) payroll disbursements are made only upon proper authorization to bona fide employees, (2) payroll disbursements are properly recorded, and (3) related legal requirements (such as payroll tax deposits) are complied with.

Unfortunately, most of these objectives were not met because of numerous failures in Johnson's internal controls system, particularly as it applied to payroll. Interestingly, many of the failures found in this case were caused by ignoring fundamental internal controls principles often learned in any basic accounting course (e.g., hiring and training competent personnel, rotating duties including proper supervision, and enforcing mandatory vacations). In addition, Johnson's computerized accounting system failed to adequately separate responsibilities for operations, asset custody, and accounting for those assets.

The following checklist is useful in summarizing the internal controls that Johnson Foundries should consider implementing in order to prevent and detect payroll fraud. Note that not all of these controls are necessary for a payroll system to meet the objectives listed above. As a matter of fact, it would probably be cost-prohibitive to implement them all in a company the size of Johnson Foundries.

- Segregation of duties at all times to separate the payroll preparation, authorization, and distribution functions.

- Monitor payroll records for (a) unusual "accounting” adjustments, such as excessive payments without deductions, large payroll reversals near year-end, etc., and (b) duplicate names/addresses or postal codes, incorrect or invalid SIN numbers and other anomalies.

- Use direct deposit, if possible and available, and minimize the use of check payments 
- Separation, segregation and oversight of amendments made to payroll master files, such as direct deposit details, to prevent unauthorized changes, etc. This should be done by a person completely independent of the payroll and accounting functions.

- Conduct surprise audits to ensure, for example, that all employees on a payroll exist and have an employee file.

- Reconcile and independently report any variations in payroll expense (e.g., monthly or quarterly) with detailed supporting documents and comparison of current payroll levels to prior years. Also reconcile payroll expense and the actual amounts paid to the authorized payroll on a regular basis; conduct an immediate follow-up whenever discrepancies are identified.

- Conduct thorough pre-employment reference checks for all payroll administrators to identify previous fraudsters.

Johnson Foundries should prepare a personnel manual that describes the company's policies regarding vacations, holidays, and sick leave. Detailed records should then be kept for each employee to ensure that these policies are being followed. However, payroll system controls should be developed that are consistent with the procedures used for all other cash disbursements. Additional segregation of duties related to the payroll function include having someone other than the payroll check signer.

The following additional questions reflect common internal accounting controls related to payroll and might indicate additional issues that should be included in a personnel manual.

o Are detailed time sheets required to document employee hours, including overtime

o Are time sheets signed by the employee's immediate supervisor authorizing payment for work?

o Are employment records maintained for each employee that detail wage rates, benefits, taxes withheld each pay period, and any changes in employment status?

o Are payroll-related taxes (federal income tax, state income tax, employee and employer share of social security, and other taxes) withheld and paid to federal and state agencies on a timely basis?

o Do the executive director and board treasurer review all the payroll tax returns?

o Do written policies and procedures exist for accounting for vacations, holidays, sick leave, and other benefits?

o Is a list of all payroll checks written, with appropriate withheld taxes, maintained either through the cash disbursement journal or a separate payroll register?

o Is a separate payroll bank account maintained?

Another way to address the lack of internal controls at Johnson Foundries is to use a checklist developed and used by external auditors when assessing the adequacy of the internal controls structure before planning the audit work. A common checklist involves the following seven areas: (Source: DeVry/Becker CPA Review manual, 2001)

1. Renumbering

- $\quad$ Time cards, checks, payroll change documents

2. Authorization

- new hires are properly documented 
- $\quad$ pay rates are authorized at the appropriate levels

- deduction authorizations are obtained at the appropriate levels

- personnel department authorizes all changes to the payroll master file

- terminations are properly documented

- check signing (authorized signatures required on all payroll checks)

3. Independent check

- Calculation and payroll amounts are internally verified

- Account classification of payroll transactions is internally verified

- Bank reconciliation of separate payroll account is prepared by individual independent of custody and recordkeeping functions

- Unclaimed checks are returned to an independent individual for follow-up

4. Documentation

- All changes to payroll are supported by authorized change documents

- Hours worked are documented by approved time records

5. Segregation of duties

- Authorization: operating department and personnel department

- Recording: Payroll department

- Custody: Treasurer signs and distributes all checks

6. Analysis and review of activities

- Bonding of employees handling cash disbursements

- Rotation of personnel in personnel department to different functions, if possible

7. Physical controls

- payroll department has no unauthorized access to computerized data processing

- unsigned checks are locked up

- treasurer signs all payroll checks and uses an imprest payroll account 


\section{$\underline{\text { Notes }}$}

